Universal Decimal Classification (UDC) number 614.7

\title{
EPIDEMIOLOGICAL ANALYSIS AND RISK ASSESSMENT OF RESPIRATORY DISEASES IN INDIVIDUALS RESIDING IN THE AREA INFLUENCED BY A LARGE PAPER MILL
}

\section{T.N. Unguryanu}

Arkhangelsk Region Department of the Federal Service on Customers' Rights Protection and Human WellBeing Surveillance Russian Federation, Arkhangelsk, 24 Gaydara St., 163061

\begin{abstract}
Epidemiological analysis of morbidity rate in the population of Novodvinsk revealed that in the area with higher level of ambient air pollution with specific substances emitted by pulp and paper mills, the incidences of acute respiratory viral infections $(223.2 \%$ ) and chronic bronchitis $(25.9 \%$ ) in the adult population and the incidences of acute bronchitis (158.0\%) and bronchial asthma (28.8 \%o) in the child population, are in 1.2-1.6-fold higher compared to the areas of the city located at some distance from the pulp and paper mill $(\chi 2=4.3-70.6 ; p=$ $0.038-\mathrm{p}<0.001)$. High risk of general toxic effects on the respiratory organs in children $(\mathrm{HI}=5.7-13.6)$ and adults $(\mathrm{HI}=4.5-6.1)$ is found, which is formed mainly due to chemicals which are present in emissions of in the pulp and paper mill.
\end{abstract}

Key words: respiratory diseases, risk assessment, pulp and paper industry.

One of the environmental factors, providing the greatest impact on public health, is the quality of the ambient air. According to the literature, ambient air pollution primarily affects the respiratory system, which functions in direct contact with the environment $[3,5,8]$. Increasing incidence of respiratory diseases due ambient air pollution was observed in many industrial regions in Russia. In the areas with high pollution, incidence of asthma, acute and chronic pneumonia, bronchitis, acute respiratory viral infections are several times higher compared to the relatively clean areas $[1,2,4,7]$. Of particular importance is the investigation of the impact of environmental pollution on human health in the areas where pulp and paper mills are located, which are associated with high values of atmospheric pollution, and where people may be subjected to significant health risks [6].

Novodvinsk is a monoindustrial town of Arkhangelsk region with a population of 42 thousand people. The town-forming enterprise is "Arkhangelsk Pulp and Paper Mill" Joint-Stock Company (OAO), one of the leading wood chemical enterprises in Europe and the Russian Federation.

The aim of the study was to carry out epidemiological analysis of distribution in the population of the incidences of respiratory diseases in different areas of the city with calculation of health risk levels resulting from exposure to the chemicals contained in the emissions produced

(C) Unguryanu T.N., 2013

Unguryanu Tatiana Nikolaevna - PhD in Medicine, Docent, Chief Specialist-Expert (e-mail: unguryanu_tn@mail.ru, tel.: 8 (818) 221-04-61). 
by “Arkhangelsk Pulp and Paper Mill” Joint-Stock Company (OAO).

Ambient air quality was studied using the monitoring data of the Federal State-funded Institution "North weather control and environmental monitoring service" and calculated concentrations of the priority pollutants emitted by "Arkhangelsk Pulp and Paper Mill" JointStock Company (OAO), obtained using modelling of chemical substances dispersion performed with a Unified program of calculation of air pollution "Ecolog" version 3.0 with calculation package "Mean". Hazard identification has shown that the greatest share of environmental pollutions in Novodvinsk is contributed by "Arkhangelsk Pulp and Paper Mill” Joint-Stock Company (OAO), which accounts for $98 \%$ of all emissions from plants located in the town. Based on the detailed analysis of criteria of inclusion and exclusion of chemicals polluting the ambient air, the priority list for the subsequent calculation of risk included 25 compounds.

According to the data of atmospheric air monitoring for the period of 2001-2011, average annual concentrations and concentrations at the 90th percentile of the suspended particles, sulfur dioxide, carbon monoxide, nitrogen dioxide, hydrogen sulfide, carbon disulfide and methyl mercaptan did not exceed the maximum permissible concentrations (MPC). Average annual concentrations of formaldehyde and benzo(a) pyrene exceeded twofold the established health standards, and their concentration at the 90th percentile exceeded the maximum permissible concentrations 2.5 and 3.4-fold, respectively.

According to the results of emission dispersion modelling the area of the town was divided into three zones: 1st - the closest to the "Arkhangelsk Pulp and Paper Mill" Joint-Stock Company (OAO); 2nd - located in the intermediate position on the distance from the "Arkhangelsk Pulp and Paper Mill" Joint-Stock Company (OAO) and the 3rd being the most distant from the plant. In the 1 st zone of the town the levels of ambient air pollution by the chemicals contained in emissions from the pulp and paper mill were 1.2-2-fold higher than the calculated concentrations of pollutants observed in the 2 nd and 3 rd zones.

A house-by-house distribution of the population into three zones of Novodvinsk has shown that the size of these sub-populations was about the same. The sub-population living in the 1 st zone, was 13,053 people in the 2 nd $-12,417$ and in the $3 \mathrm{rd}-13,398$ people.

The morbidity rate in different zones of the town was studied for the period 2001-2009, based on electronic database of the State-Funded Health Institution "Novodvinsk Clinical Hospital" in which disease cases are recorded in accordance with the accounting medical document "Letter of ambulatory patient" (form No.025-6(7)/u-89). Testing of the null hypothesis of no difference between the levels of morbidity in different zones of the town was carried out using the chi-square $\left(\chi^{2}\right)$ and Fisher's exact tests. The level of significance, at which the null 
hypotheses were evaluated, was 0.05. Statistical data analysis was performed using SPSS 18.0 software for Windows and Epi Info 3.4.1 program.

In the structure of primary morbidity in children and adults living in Novodvinsk, respiratory diseases occur with the highest incidence (58 and 30\%, respectively). Analysis of distribution of incidence of respiratory diseases by zones of the town has shown that among children living in the 1st zone, the incidence of acute bronchitis (158.0\%) and bronchial asthma (28.8\%o) were significantly 1.2-1.6-folds higher compared with the incidence among children living in two other zones (Table 1).

Among the adult population of the 1st zone, the incidence of acute respiratory viral infections (232,2\%) and chronic bronchitis (25,9\%) 1.1-1.2-folds exceeded the incidence of such diseases in subpopulations of the 2 nd and 3rd zones, but statistically significant differences in total morbidity rates of chronic bronchitis were found only between the 1 st and the 3 rd zones.

Mean levels of total incidence of bronchial asthma in total child population (28.8 \% ), as well as in children up to 2 years old (8.8 \%), 3-4 years old (23.6\%), 7-9 years old (32.0\%o), 10-14 years old (37.3\%), and 15-17 years old (34.9\%), living in the 1st zone, were statistically significantly higher than the incidence among children in the respective age groups living in 2nd and 3rd zones (Table 2).

Table 1

Morbidity rates in different zones of Novodvinsk for the period of 2001-2009 (mean incidence $\pm \mathbf{9 5 \%}$ confidence interval per 1000 persons in the relevant age group)

\begin{tabular}{|c|c|c|c|c|c|c|}
\hline Group, age & Diagnosis & ICD-10 & Zone 1 & Zone 2 & Zone 3 & $\mathrm{p} * * *$ \\
\hline \multirow{2}{*}{$0-17$} & Acute bronchitis* & $\mathrm{J} 20-22$ & $158,0 \pm 14,1$ & $124,4 \pm 13,4$ & $137,3 \pm 13,3$ & $\begin{array}{l}\mathrm{p} 1-2<0,001 \\
\mathrm{p} 1-3=0,038\end{array}$ \\
\cline { 2 - 6 } & Bronchial asthma** & $\mathrm{J} 45$ & $28,8 \pm 16,9$ & $20,9 \pm 15,9$ & $18,2 \pm 14,3$ & $\begin{array}{l}\mathrm{p} 1-2<0,001 \\
\mathrm{p} 1-3<0,001\end{array}$ \\
\hline \multirow{2}{*}{18 and older } & $\begin{array}{c}\text { Acute respiratory viral } \\
\text { infections* }\end{array}$ & $\mathrm{J} 00-06$ & $223,2 \pm 80,0$ & $182,2 \pm 75,0$ & $211,0 \pm 76,0$ & $\begin{array}{l}\mathrm{p} 1-2<0,001 \\
\mathrm{p} 1-3<0,031\end{array}$ \\
\cline { 2 - 7 } & Chronic bronchitis** & $\mathrm{J} 40-42$ & $25,9 \pm 3,1$ & $23,7 \pm 3,0$ & $21,1 \pm 2,7$ & $\begin{array}{l}\mathrm{p} 1-2=0,296 \\
\mathrm{p} 1-3=0,020\end{array}$ \\
\hline
\end{tabular}

Note: ${ }^{*}$ - Primary incidence rate;

** - Total morbidity rate;

${ }^{* * *}$ - Level of statistical significance achieved. 
Total incidence of bronchial asthma $\left(\mathrm{J}_{45}\right)$ in different age groups of children in the zones of Novodvinsk for the period of 2001-2009

\begin{tabular}{|c|c|c|c|c|c|c|c|}
\hline \multirow[b]{2}{*}{ Group, age } & \multicolumn{2}{|c|}{ Zone 1} & \multicolumn{2}{|c|}{ Zone 2} & \multicolumn{2}{|c|}{ Zone 3} & \multirow{2}{*}{$\begin{array}{l}\mathrm{P} \text {-value } \\
\text { achieved }\end{array}$} \\
\hline & $\begin{array}{l}\text { Absolute } \\
\text { number }\end{array}$ & per 1000 & $\begin{array}{l}\text { Absolute } \\
\text { number }\end{array}$ & per 1000 & $\begin{array}{l}\text { Absolute } \\
\text { number }\end{array}$ & per 1000 & \\
\hline $0-2$ & 33 & 8,8 & 25 & 7,1 & 11 & 2,9 & $\begin{array}{l}\text { p1-2 }=0,386 \\
\text { p1-3 }<0,001\end{array}$ \\
\hline $3-4$ & 57 & 23,6 & 27 & 11,7 & 27 & 11,2 & $\begin{array}{l}\text { p1-2<0,001 } \\
\text { p1-3 }<0,001\end{array}$ \\
\hline $5-6$ & 64 & 26,1 & 52 & 25,1 & 55 & 22,4 & $\begin{array}{l}\text { p1-2 }=0,807 \\
\text { p1-3 }=0,339\end{array}$ \\
\hline $7-9$ & 113 & 32,0 & 85 & 27,3 & 59 & 15,8 & $\begin{array}{l}\text { p1-2 }=0,192 \\
\text { p1-3 }<0,001\end{array}$ \\
\hline $10-14$ & 230 & 37,3 & 156 & 29,0 & 172 & 30,0 & $\begin{array}{l}\text { p1-2 }=0,003 \\
\text { p1-3 }=0,009\end{array}$ \\
\hline $15-17$ & 173 & 34,9 & 95 & 20,7 & 95 & 19,3 & $\begin{array}{l}\text { p1-2 }<0,001 \\
\text { p1-3 }<0,001\end{array}$ \\
\hline
\end{tabular}

The highest degree of differences was observed among children of 3-4 years old, for whom the incidence of diseases in the 1st zone was 2-fold higher compared with that for children living in two other zones. In the age group 15-17 years, the total incidence of asthma was 1.7folds higher than the incidence of the disease identified in the 2 nd and 3 rd zones. In other age groups (up to 2 years, 7-9 years and 10-14 years old) the total incidence ratio between the 1st and 2nd zones was 1.2, and in regard to the incidence of the 3rd zone - the ratio was 1.3 to 3 .

For calculation of the risk of general toxic effects resulting from exposure to chemicals polluting the ambient air, daily equivalent doses were defined. It was found that for children in the age groups of 1-6 years and 7-17 years, the values of daily doses were 2.2- and 1.3-folds, respectively, higher than those for the adult population.

Analysis of hazard indexes (HI) showed that there is a high risk of respiratory diseases resulting from exposure to ambient air pollutants. Hazard indexes at the level of median concentrations and the 90th percentile for children in the age group of 1-6 years were 9.93 и 13.58 , respectively.

For children of 7-17 years old and for adults, a high risk of adverse respiratory effects was observed only at the upper bound of exposure (HI90 = 7.83 and 6.1, respectively). At the level of median concentrations of pollutants, the risk level for school-age children and adults is characterized as "alarming" (HI50 $=5.73$ and HI50 $=4.49$, respectively).

The largest contribution to the risk of non-carcinogenic respiratory effects is made by formaldehyde (36.2\%), suspended substances (15.7\%), nitrogen dioxide (10.2\%), chlorine dioxide (9.1\%), hydrogen sulfide (8.2\%), methyl mercaptan $(6.0 \%)$, chloride $(6.0 \%)$ and sulfuric 
acid (5.0\%). Attributable number of complaints about obstructive pulmonary disease in the general population, resulted from the influence of suspended particles, is 15 cases per year or 3\% ( $95 \%$ confidence interval: $0-6.3 \%$ ). Mortality rate due to respiratory diseases is 2 cases or $5.4 \%$ (95\% confidence interval: $2.8-11.3 \%)$.

Thus, epidemiological analysis of incidences of respiratory diseases of Novodvinsk showed higher levels of respiratory diseases among children and adults living in the proximity to a paper mill. Application of the risk assessment methodology found a high risk of general toxic effects of the respiratory organs in children and adults, which is formed mainly due to chemical substances contained in mill emissions.

\section{References}

1. Karavaev V.E., Orlova S.N., Alenina T.M., Al'per I.A., Kozyreva I.I. Vlijanie jekologo-klimaticheskih faktorov na chastotu i techenie stenozirujushhih laringotraheitov pri ORZ u detej [The impact of environmental and climatic factors on the frequency and course of obstructing laryngotracheitises in children with acute respiratory diseases]. Gigiena i sanitarija, 2007, no. 2, pp. 7-9.

2. Levashova T.Ju., Kvartovkina L.K. Rasprostranennost' bronhial'noj astmy na territorijah s razlichnoj stepen'ju jekologicheskogo neblagopoluchija [The prevalence of bronchial asthma in areas with various levels of environmental pollution]. Gigiena $i$ sanitarija, 2004, no. 1, pp. 2829.

3. Skachkov M.V., Skachkova M.A., Vepeshhagin N.N., Kopneev A.G. Mehanizm fopmipovanija ppedpaspolozhennosti $\mathrm{k}$ ostpym pespipatopnym zabolevanijam $\mathrm{v}$ pegionah $\mathrm{s}$ vysokoj antpopogennoj nagpuzkoj [The mechanism of developing the susceptibility to acute respiratory diseases in areas with high levels of man-made impact]. Gigiena i sanitarija, 2002, no. 5, pp. 39-42.

4. Efimova N.V., Katul'skaja O.Ju., Abramatec E.A., Nesmejanova N.N., Tihonova I.V. Osobennosti formirovanija hronicheskoj patologii organov dyhanija u podrostkov Angarska [The characteristics of the development of chronic respiratory pathologies in adolescents in the city of Angarsk]. Gigiena i sanitarija, 2011, no. 1, pp. 83-85.

5. Buharin O.V., Zverev A.F., Kartashova O.L., Kirgizova S.B. Prognozirovanie razvitija boleznej organov dyhanija u detej, prozhivajushhih na tehnogenno zagrjaznennyh territorijah [Forecasting the development of respiratory diseases in children residing in technogenically polluted areas]. Gigiena i sanitarija, 2010, no. 6, pp. 76-78.

6. Ungurjanu, T.N., Novikov S.M., Buzinov R.V., Gudkov A.B. Risk dlja zdorov'ja naselenija ot himicheskih veshhestv, zagrjaznjajushhih atmosfernyj vozduh, v gorode s razvitoj celljulozno-bumazhnoj promyshlennost'ju [Human health risk from chemical substances polluting ambient air in a city with a heavily developed paper-making industry]. Gigiena $i$ sanitarija, 2010, no. 4, pp. 21-24.

7. Stamova L.G., Chesnokova E. A. Zagrjaznenie atmosfernogo vozduha i ego vlijanie na zabolevaemost' organov dyhanija u detej [Ambient air pollution and its influence on the incidence of respiratory diseases in children]. Gigiena i sanitarija, 2005, no. 5, pp. 28-31.

8. Kiku P.F., Kozjavina N.V., Vitkina T.I., Kalinina E.P. Jekologo-gigienicheskie i immunologicheskie problemy boleznej organov dyhanija [Ecological, environmental health and immune issues of respiratory diseases]. Vladivostok: Izd-vo DVGU, 2005. 200 p. 